\title{
Bacterial Biodiversity of Extra Virgin Olive Oils and Their Potential Biotechnological Exploitation
}

\author{
Francesco Fancello ${ }^{\dagger} \odot$, Chiara Multineddu ${ }^{\dagger}$, Mario Santona ${ }^{\oplus}$, Pierfrancesco Deiana $₫$, \\ Giacomo Zara, Ilaria Mannazzu, Marilena Budroni ${ }^{\circ}$, Sandro Dettori and Severino Zara * \\ Dipartimento di Agraria, Viale Italia 39, University of Sassari, 07100 Sassari, Italy; fancello@uniss.it (F.F.); \\ cmulti@uniss.it (C.M.); msantona@uniss.it (M.S.); pideiana@uniss.it (P.D.); gzara@uniss.it (G.Z.); \\ imannazzu@uniss.it (I.M.); mbudroni@uniss.it (M.B.); sdettori@uniss.it (S.D.) \\ * Correspondence: szara@uniss.it \\ + These authors contributed equally to this work.
}

Received: 3 December 2019; Accepted: 7 January 2020; Published: 10 January 2020

\begin{abstract}
Bacterial diversity of 15 extra virgin olive oils, obtained from different Italian varieties, including Frantoio, Coratina, Bosana, and Semidana, was analyzed in this study. All bacterial isolates were genotyped using RAPD and REP-PCR method and grouped by means of cluster analyses. Sequencing of $16 \mathrm{~S}$ rDNA of 51 isolates, representative of 36 clusters, led to the identification of Bacillus spp., Brevibacillus spp., Micrococcus spp., Staphylococcus spp., Pantoea spp., Kocuria spp., Lysinbacillus spp., and Lactobacillus spp., most of which reported for first time in olive oils. Phenotypic characterization of the 51 isolates, some of which ascribed to potentially probiotic species, indicate that two of them have beta-glucosidase activity while $37 \%$ present lipolytic activity. Preliminary evaluation of probiotic potential indicates that $31 \%$ of the isolates show biofilm formation ability, $29 \%$ acidic $\mathrm{pH}$ resistance, and $25 \%$ bile salt resistance. Finally, $29 \%$ of the isolates were sensitive to antibiotics while the remaining $71 \%$, that include bacterial species well-recognized for their ability to disseminate resistance genes in the environment, showed a variable pattern of antibiotic resistance. The results obtained underline that microbial diversity of extra virgin olive oils represents an unexpected sink of microbial diversity and poses safety issues on the possible biotechnological exploitation of this microbial biodiversity.
\end{abstract}

Keywords: Bacillus spp.; L. rhamnosus; antimicrobial resistance; Extra Virgin Olive Oil (EVOO)

\section{Introduction}

Over the last 15 years, microbiological research has established that freshly produced virgin olive oils have a rich microflora. Yeasts and bacteria are capable of conditioning the physicochemical and sensorial characteristics of the oil through their high enzymatic activities [1]. Certain yeasts are considered beneficial as they [2] can improve the sensorial characteristics of the oil during storage, whereas other yeasts are considered harmful as they can damage the quality of the oil through the hydrolysis of triacylglycerols and the production of unpleasant flavors [3-9]. The presence of these microbes, particularly the yeasts but also bacteria $[9,10]$, possibly arises from their transfer into the oil from the olive carposphere during the extraction process. The microorganisms in olive oil are often below the limits of detection with standard culture methods [10] due to the strong selective pressure exerted by the oil's antimicrobial compounds and the fact that the oil's fatty acids constitute the sole source of carbon and energy for any microbial contaminates. These factors explain the scarcity of information about olive oil microflora. According to Koidis et al. [11], the presence of mini droplets of water in freshly produced olive oils support microbe survival in this hostile environment. Although the presence of microbes in olive oil may also result from manufacturing 
contaminations [12], a wealth of literature now indicates the presence of a highly specific microflora, especially in relation to yeasts [13]. By contrast, very limited data exist about the presence of bacteria. Recently, the groups of Santona et al. [9] and Pizzolante et al. [10] described the presence of different genera and species of bacteria in extra virgin olive oils that were at least one year old. While the effects of yeasts on the sensorial properties and quality of olive oils have been investigated in great depth [13], much less is known about the effects of bacteria. Olive oil microorganisms also possess great biotechnological potential thanks to their ability to tolerate and/or metabolize fats and greases in general; for these reasons, selected bacteria are frequently used for the bioremediation of oily wastewaters and contaminated soils or as a source of enzymes (e.g., lipases) or even biosurfactants [10]. Indeed, in this last cited study, the authors identified and characterized two bacteria strains of Pantoea septica able to produce carotenoids and bioemulsifiers. Another potential use of such bacteria is related to their probiotic characteristics, as recently demonstrated by Santona et al. [9]. Finally, it is important to recognize and stress that the presence of these microorganisms could also affect the safety of the olive oils due to the possibility of the bacteria possessing antibiotic resistance genes [14]. Considering that olive oil, due to its constituents, represents both a strong selective substrate for microbial growth microflora and a reservoir of microbial biodiversity, the aim of this work was to isolate, identify, and characterize bacteria from olive oils obtained from different national and regional varieties, in order to obtain bacteria with specific features for a potential biotechnological exploitation.

\section{Materials and Methods}

\subsection{Isolation of Bacteria from Oil Samples}

Olive samples were harvested (2016/2017 season) from an experimental olive grove belonging to the Department of Agriculture of the University of Sassari, situated in Oristano, Sardinia (Italy) (for more details see Deiana et al. [15]). Olive varieties used were: Frantoio, Coratina, Bosana, Semidana, Bianca di Villacidro, Confetto, Nera di Gonnos, Nera di Oliena, Palma, Paschixedda, Pizz'e carroga, Sivigliana da olio, Terza grande, Tonda di Cagliari, Tonda di Villacidro.

The production of the monovarietal olive oils was performed in an experimental mill, also located in Oristano, as described by Deiana et al. [16]. Bacterial isolation was performed under aseptic conditions according to Santona et al. [9] by using an enrichment method, with slight modifications. In brief, $10 \mathrm{ml}$ oil was mixed with $90 \mathrm{ml}$ YEPD (1\% yeast extract, $2 \%$ peptone, and $2 \%$ glucose) in $250 \mathrm{ml}$ Erlenmeyer flanged flasks and incubated with agitation for $24 \mathrm{~h}$ at $28^{\circ} \mathrm{C}$. Next, $100 \mu \mathrm{L}$ aliquots were taken and 1/10 dilutions plated on six distinct culture media and maintained under different conditions as described below. Plate count agar (PCA, Merck, Italy) maintained at $28^{\circ} \mathrm{C}$ for $48 \mathrm{~h}$ was utilized as the general medium for the viable mesophilic bacteria population, PCA maintained at $5^{\circ} \mathrm{C}$ for 7 days was used for psychrophilic bacteria, PCA maintained at $45^{\circ} \mathrm{C}$ for $48 \mathrm{~h}$ was used for thermophilic bacteria; and PCA was used for spore-forming bacteria treated at $80^{\circ} \mathrm{C}$ for $15 \mathrm{~min}$. MRS (De Man Rogosa Sharpe, Merck, Italy) agar was used to grow lactic acid bacteria at $30^{\circ} \mathrm{C}$, under both aerobiotic and anaerobiotic conditions (Thermo Scientific ${ }^{\mathrm{TM}}$ Oxoid AnaeroGen, Basingstoke, UK). Finally, YEPD and WL nutrient agar (Microbiol, CA, Italy) were utilized at $28^{\circ} \mathrm{C}$ for $48 \mathrm{~h}$ for filamentous fungi, yeasts, and bacteria. All analyses were performed in triplicate. Randomly selected colonies, representative of the different colony morphologies (shape, color, dimension, halos, etc.), were manually picked up, re-streaked on BHI (brain heart infusion medium, Microbiol, CA, Italy), and stored at $-80{ }^{\circ} \mathrm{C}$ until further analyses.

\subsection{DNA Isolation, Cluster Analyses, and Molecular Characterization of Bacteria}

Isolated bacterial colonies were inoculated into $15 \mathrm{~mL}$ sterile polypropylene tubes containing $7 \mathrm{ml} \mathrm{BHI} \mathrm{broth} \mathrm{and} \mathrm{kept} \mathrm{overnight} \mathrm{at} 28{ }^{\circ} \mathrm{C}$ with agitation. The following day, samples were subjected to DNA isolation according to Santona et al. [9]. Next, in order to reduce genotypic redundancy among the strains, DNAs from every isolate were subjected to randomly amplified 
polymorphic DNA-polymerase chain reaction fingerprint analysis (RAPD-PCR), as described in Fancello et al. [17] by using the primer M13 (5' GAGGGTGGCGGTTCT-3') and REP-PCR as described by Mangia et al. [18] using the (GTG)5 oligonucleotide primer (5'-GTGGTGGTGGTGGTG-3'). For the molecular characterization, bacterial strains identified by RAPD-PCR were subjected to cluster analyses (InfoQuest version 4.5, Biorad), and strains representative of each cluster were chosen for further characterization. The DNAs of every representative strain were subjected to PCR of the $16 \mathrm{~S}$ ribosomal DNA fragment (1500 bp) using the universal primers W001 (5'-AGAGTTTGATCMTGGCTC-3') and W002 (5'-GNTACCTTGTTACGACTT-3') [19]. Amplicons were then purified using the QIAquick PCR Purification Kit (QIAGEN GmbH, Hilden, Germany), following the manufacturer's instructions, and sequenced. Sequencing was performed by Macrogen (Hong Kong, China). Sequencing was compared with those presented in the GenBank database using the BLAST program (http://www.ncbi.nih.gov/ BLAST/) and with those in the Ribosomal Database Project (http://rdp.cme.msu.edu/edu/index.jsp).

\subsection{Enzymatic Characterization of Bacteria}

All enzymatic tests were performed in triplicate and according to the methods reported in Santona et al. [9] with slight modifications. $\beta$-glucosidase activity was tested on agar plates with arbutin as substrate on YNB medium (6.7 g/L Yeast Nitrogen Base, Difco), plus $5 \mathrm{~g} / \mathrm{L}$ arbutin (Sigma, St. Louis, MO, USA) and $20 \mathrm{~g} / \mathrm{L}$ agar, at $\mathrm{pH}$ 5.0. Immediately after sterilization ( $121^{\circ} \mathrm{C}$ for $\left.15 \mathrm{~min}\right), 2$ $\mathrm{mL}$ of a sterile $1 \%(w / v)$ ferric ammonium citrate solution was added to $100 \mathrm{ml}$ of medium and then poured into Petri dishes ( $15 \mathrm{~mL}$ medium per plate). Each plate was inoculated with 8 different isolates, incubated at $25^{\circ} \mathrm{C}$, and examined after 2, 4, 6, and 8 days (d). A non-inoculated plate served as the control. Strains positive for $\beta$-glucosidase activity resulted in the development of a dark brown color in the agar due to hydrolysis of the substrate [20]. A code based on the color of the halo, indicative of the level of enzyme activity, was ascertained for each colony: White: $\mathrm{N}$ (no activity), light grey: W (weak activity), grey: M (moderate activity), and black: $S$ (strong activity).

$\beta$-glucanase activity was assessed by streaking the isolates onto brain heart infusion (BHI) plates containing $0.2 \%$ lichenan (Sigma). The plates were incubated for $5 \mathrm{~d}$ at $25^{\circ} \mathrm{C}$. The resulting colonies were then rinsed off the plates using distilled water and the plates stained with $0.03 \%$ Congo Red. A clear zone, around which a colony had been, identified $\beta$-glucanase activity [21]. A code based on the diameter of the halo and again indicative of the level of enzyme activity was allocated to each colony: N: No halo, W: Weak halo, M: Moderate halo, S: Strong halo.

Lipase activities were assessed on spirit blue agar (Sigma-Aldrich, St. Louis, MO, USA), which includes the pancreatic digest of casein $(1 \%)$, yeast extract $(0.5 \%)$, agar $(1.7 \%)$, and spirit blue $(0.015 \%)$. Lipase substrate mix contains Cottonseed oil (C7767, Sigma-Aldrich) and Tween 80 (Sigma, cat. 93,780). Lipase substrate was added to the medium following the manufacturer's instructions. Plates were inoculated with the same amounts of cell suspensions and incubated at $25{ }^{\circ} \mathrm{C}$ for $48 \mathrm{~h}$. Lipolysis was assessed by the presence of a halo around each colony (N: No halo, W: Weak halo, M: Moderate halo, S: Strong halo).

For decarboxylase activity, agar plates were prepared as follows: Aliquots of $0.1 \mathrm{~g} / \mathrm{L}$ glucose, 0.06 $\mathrm{g} / \mathrm{L}$ of Bromocresol purple (Sigma- Aldrich), and $1 \mathrm{~g} / \mathrm{L}$ of each amino acid (L-lysine, L-phenylalanine, L-tyrosine, L-histidine, and L-arginine) (used singularly and in combination) were added, and $15 \mathrm{~g} / \mathrm{L}$ agar was suspended in $900 \mathrm{~mL}$ of distilled water. After sterilization, $100 \mathrm{~mL}$ filtered-sterilized yeast nitrogen base (Difco) solution $(6.7 \% \mathrm{w} / \mathrm{v})$ was added, adjusted to have a final $\mathrm{pH}$ 5.3. Isolates were streaked on the agar plates (of the medium prepared above) and then incubated at $25^{\circ} \mathrm{C}$ for $4 \mathrm{~d}$. The reaction was considered positive if a violet halo appeared around the colonies [22]. A code based on the color of the halo and indicative of the level of enzyme activity was ascertained for each colony: White: N, light grey: W, grey: $\mathrm{M}$, and black: S.

For catalase activity, isolates were inoculated into 96-well plates containing liquid BHI medium and incubated overnight at $30^{\circ} \mathrm{C}$. Enzyme activity was evaluated by adding, $2-3$ minutes before the analysis, $3 \%(v / v)$ hydrogen peroxide to the inocula. The presence or absence of bubbles was indicative 
of the presence or absence of catalase activity, respectively, and the level of activity was once again graded accorded to the $\mathrm{N}, \mathrm{W}, \mathrm{M}, \mathrm{S}$ code.

\subsection{Biofilm Formation}

Biofilm formation was evaluated as described by Bou Zeidan et al. [23] and Santona et al. [9] with some modifications. In brief, $100 \mu \mathrm{L}$ aliquots of cell suspensions containing $5 \times 10^{6} \mathrm{cells} / \mathrm{ml}$ in M9 minimal salt medium (Gibco) were dispensed into 96-well polystyrene microtiter plates (Costar 3595 , Corning, NY, USA). Cell suspensions were incubated statically at $25^{\circ} \mathrm{C}$ for $24 \mathrm{~h}$. The day after, $125 \mu \mathrm{L}$ of the cell suspension and an equal volume of $0.1 \%(w / v)$ crystal violet were added to each well. After $30 \mathrm{~min}$, the wells were washed three/four times with tap water and cell adherence quantified by solubilizing the retained crystal violet in $125 \mu \mathrm{L} \mathrm{30 \%} \mathrm{CH} 3 \mathrm{COOH}$ for $15 \mathrm{~min}$ at room temperature. Next, $50 \mu \mathrm{L}$ of these solutions was transferred to fresh 96-well polystyrene microtiter plates, and absorbance at $550 \mathrm{~nm}$ was measured spectrophotometrically. Classification of adherence capabilities was performed according to Extremina et al. [24]. The average optical density (OD) values were calculated for all tested strains and negative controls (nc), and the cut-off value (ODc) was established. ODc was defined as the average OD of the negative control (ODnc) plus three standard deviations of the negative control (SDnc), ODc $=$ average ODnc $+(3 \times$ SDnc $)$. Strains were divided into the following categories: $\mathrm{OD} \leq \mathrm{ODc}=$ non-biofilm producer, $\mathrm{ODc}<\mathrm{OD} \leq 2 \times \mathrm{ODc}=$ weak biofilm producer, $2 \times$ ODc $<$ OD $\leq 4 \times$ ODc $=$ moderate biofilm producer, $4 \times$ ODc $<$ OD $=$ strong biofilm producer.

\subsection{Screening of Bacteria for Tolerance to Acidic $\mathrm{pH}$ and Bile}

To assess tolerance to acidic $\mathrm{pH}$, bacterial strains were inoculated into 24-well plates in liquid $\mathrm{BHI}$ and incubated at $25^{\circ} \mathrm{C}$ overnight. The following day, cells were aspirated, and a concentration of $10^{7}$ cells $/ \mathrm{mL}$ was then inoculated into fresh 24-well plates containing $1 \mathrm{~mL}$ liquid $\mathrm{BHI}$ adjusted to $\mathrm{pH}$ 2.5 with $12 \mathrm{~N} \mathrm{HCl}$ and incubated at $37^{\circ} \mathrm{C}$ for $2 \mathrm{~h}$. Samples were removed after $2 \mathrm{~h}$, and the viable strains were assessed by plating $10 \mu \mathrm{L}$ of cell cultures on new BHI media and incubating the plates for 24 and $48 \mathrm{~h}$ at $25^{\circ} \mathrm{C}$.

To assess tolerance to bile salts, a $0.5 \%$ saturated bile solution was prepared by dissolving powdered bile salts (Fluka cod. \#48305) in BHI broth and filter sterilized using a $0.2 \mathrm{~mm}$ filter. Bacterial strains were inoculated into 24 -well plates in liquid BHI and incubated at $25{ }^{\circ} \mathrm{C}$ overnight. The following day, cells were aspirated, and $10^{7}$ cells $/ \mathrm{mL}$ were inoculated into 24 -well plates containing 1 $\mathrm{mL}$ of bile solution and incubated at $37^{\circ} \mathrm{C}$ for $2 \mathrm{~h}$. Wells with no bile solution were used as controls. Samples were taken after $2 \mathrm{~h}$, and the viable strains were assessed by plating $10 \mu \mathrm{L}$ of cell cultures on new BHI media and incubating the plates for 24 and $48 \mathrm{~h}$ at $25^{\circ} \mathrm{C}$. All screenings were performed in triplicate.

\subsection{Antimicrobial Agent's Susceptibility Test}

The MICs of eight antimicrobial agents were determined by the use of broth microdilution methods according to the Clinical and Laboratory Standard Institute [25], the European Committee on Antimicrobial Susceptibility Testing (EUCAST; www.eucast.org), and ISO standards. In particular, plates for bacteria isolates were used containing serial 2-fold dilutions of the following antibiotics: ampicillin, ciprofloxacin, clindamycin, chloramphenicol, erythromycin, streptomycin, tetracycline, and vancomycin. For Bacillus spp., Brevibacillus spp., and Lysinibacillus spp., the MICs were determined by use of a modified Clinical and Laboratory Standards Institute (CLSI) method according to Agersø et al. [14]. The MIC of L. rhamnosus isolate was evaluated by the ISO 10932 standard, while the MICs of Staphylococcus spp., Micrococcus spp., and Kocuria spp. were evaluated according to CLSI guidelines for Staphylococcus spp. The MICs of isolates of Pantoea spp. were evaluated according to CLSI guidelines for Enterobacteriaceae. Epidemiological cut-off (ECOFF) values were retrieved from the European Food Safety Authority (EFSA) [26,27], from Agersø et al. [14]. For antibiotics not covered by EFSA, breakpoints from CLSI were used [25]. 


\section{Results and Discussion}

In our previous work [9], we made some first steps toward characterizing the bacterial microbiota of olive oil, whereas it constituted the primary goal of this present work, focusing on 15 different Italian olive varieties present in the experimental olive grove belonging to the University of Sassari. Through the isolation, molecular identification, and characterization of the microorganisms obtained from the different extra virgin olive oils analyzed, it was possible to elucidate, by using culture-dependent methods, the composition of the bacterial microbiota of the olive oils obtained. The total bacterial count was estimated using non-selective media (YEPD, WL, and PCA). Isolation of the oils' microflora was performed using the enrichment method; thus, the estimates of concentration do not reflect the $\mathrm{CFU} / \mathrm{mL}$ effectively present in the oils. Nonetheless, the CFU/ml concentration for bacteria present in olive oils subjected to enrichment was always an average of $5 \times 10^{3}$ for all the oils tested. This is probably due to the strong selective pressure of many antimicrobial compounds present in the olive oils [28].

\subsection{Molecular Characterization of the Isolates}

In order to compare the genotypic redundancy among the strains isolated from olive oils, the RAPD and REP-PCR techniques were used. The fingerprinting methods used showed a good reproducibility with a very similar banding pattern amongst three independent DNA preparations of three biological replicates of the same isolate. In fact, the reproducibility of the electrophoresis pattern was $90 \%$, which is the cut-off used for separating the isolates at strain level. The 72 isolates were grouped into 36 clusters with a cut-off value of $90 \%, 24$ of which are formed by a single strain, proving the higher genotypic variability of the isolates from olives oils (Figure S1). No patterns were observed among the strains analysed. We did not find any linking between isolate origin and genotype of the strains. The 16S rDNA sequencing of the 52 isolated strains, obtained as representative of each cluster, revealed that the isolates mainly belonged to Bacillus spp., Brevibacillus spp., Micrococcus spp., Staphylococcus spp., Pantoea spp., Lysinibacillus spp., Kocuria spp., and Lactobacillus spp. In particular, among the Bacillus spp. we found B. amyloliquefaciens (11 strains), B. subtilis (5 strains), and B. megaterium (1 strain). Among Brevibacillus spp., we found Br. agri (9 strains), Br. invocatus (6 strains), and Br. parabrevis (3 strain). Among Staphylococcus spp. we found one strain of S. pasteuri and S. epidermidis and two strains of S. hominis. We also identified single strains of Kocuria rhizophila and of Lactobacillus rhamnosus. The other isolates were only identified at the genus level (4 strains of Brevibacillus spp., three strains of Micrococcus spp., three Pantoea spp., and one strain of Lysinibacillus spp.) (Table 1). As expected, most of the different genera and species found in the different olive oils analyzed are typical of natural environments, such as soils and plants, whereas some other genera/species identified are typical of the human host environment.

B. subtilis and B. amyloliquefaciens species are well-known for their plant growth-promoting rhizobacteria (PGPR) activity and have been widely used to promote plant growth and antagonize numerous plant pathogens [29]. For example, B. amyloliquefaciens is thought to promote plant growth through the biosynthesis of indole-3-acetic acid (IAA) molecules, enriching the available nitrogen, phosphate, and potassium in soil and improving soil health via a synergistic enhancement of several soil enzymes [30]. B. subtilis, on the other hand, is involved in the expression of specific genes and hormones, such as 1-aminocyclopropane-1-carboxylate deaminase (ACC) [31]. Of Brevibacillus spp., Br. agri strains have been found to tolerate and to be capable of degrading toluene [31], as well as able to reduce hexavalent chromium, preventing the generation of harmful byproducts [32]. A strain of $B r$. invocatus has been used for producing hydrogen from glucose [33], and Br. parabrevis has been studied for its ability to degrade low density polyethylene films (LDPE) [34]. 
Table 1. Bacteria Isolates divided per species and olive oil varieties.

\begin{tabular}{|c|c|c|c|c|c|c|c|c|c|c|c|c|c|c|c|c|}
\hline Strains & $\begin{array}{c}\text { No. } \\
\text { Isolates }\end{array}$ & Frantoio & Coratina & Bosana & Semidana & $\begin{array}{c}\text { Bianca di } \\
\text { Villacidro }\end{array}$ & Confetto & $\begin{array}{l}\text { Nera di } \\
\text { Gonnos }\end{array}$ & $\begin{array}{l}\text { Nera di } \\
\text { Oliena }\end{array}$ & Palma & Paschixedda & $\begin{array}{c}\text { Pizz'e } \\
\text { Carroga }\end{array}$ & Sivigliana & $\begin{array}{c}\text { Terza } \\
\text { Grande }\end{array}$ & $\begin{array}{c}\text { Tonda di } \\
\text { Cagliari }\end{array}$ & $\begin{array}{r}\text { Tonda di } \\
\text { Villacidro }\end{array}$ \\
\hline B. amyloliquefaciens & 11 & - & - & - & - & 9 & 1 & - & - & - & - & - & - & - & - & 1 \\
\hline B. megaterium & 1 & - & - & - & - & 1 & - & - & - & - & - & - & - & - & - & - \\
\hline B. subtilis & 5 & - & - & - & - & 1 & - & - & - & - & - & 4 & - & - & - & - \\
\hline Br. agri & 9 & 1 & - & - & 2 & - & - & 2 & 1 & 1 & - & - & 2 & - & - & - \\
\hline Br. parabrevis & 3 & - & - & - & - & - & - & - & 1 & 1 & - & - & - & 1 & - & - \\
\hline Br. invocatus & 6 & - & - & - & 3 & - & - & - & . & 2 & - & - & 1 & - & - & - \\
\hline L. rhamnosus & 1 & 1 & - & - & - & - & - & - & - & - & - & - & - & - & - & - \\
\hline S. epidermidis & 1 & - & - & - & - & - & - & - & - & - & 1 & - & - & - & - & - \\
\hline S. pasteuri & 1 & - & - & - & - & - & - & - & - & - & - & - & - & 1 & - & - \\
\hline S. hominis & 2 & - & - & 1 & - & - & - & - & - & - & - & - & - & - & 1 & - \\
\hline K. rhizophila & 1 & - & 1 & - & - & - & - & - & - & - & - & - & - & - & - & - \\
\hline Brevibacillus spp. & 4 & - & - & - & 2 & - & - & - & 2 & - & - & - & - & - & - & - \\
\hline Pantoea spp. & 3 & - & - & - & 3 & - & - & - & - & - & - & - & - & - & - & - \\
\hline Lysinbacillus spp. & 1 & - & - & - & 1 & - & - & - & - & - & - & - & - & - & - & - \\
\hline Micrococcus spp. & 3 & - & - & 1 & 1 & - & - & - & - & - & - & - & - & - & 1 & - \\
\hline Total & 52 & & & & & & & & & & & & & & & \\
\hline
\end{tabular}

Hyphen (-) indicates that none of the isolates of the specific species is present in a certain variety. 
We identified two strains of Pantoea at the genus level. Pantoea is a genus of gram-negative bacilli belonging to Enterobacterales, which may be beneficial or harmful to plants [35]. Recently, Pizzolante et al. [10] identified and characterized two strains of P. septica from olive oil that were able to produce carotenoids and bioemulsifiers, whereas Vuletin Selak et al. [36] sequenced the genome of a Pantoea spp. isolated from an olive knot. In olive knot disease, the nonpathogenic bacterial species Pantoea agglomerans and Erwinia toletana, both of which can live as epiphytes or endophytes, coexist with the pathogenic bacterium Pseudomonas savastanoi pv. savastanoi, the causal agent of knot disease [37-39].

Organisms in the genus Kocuria are environmental bacteria, as well as human skin and oropharynx mucosal commensals [40]. The actinobacteria K. rhizophila is gram-positive, halotolerant, and shows a high capacity to adapt to any specific ecological niche, being found in a large variety of environments, including marine sediment [41-43]. K. rhizophila has also been isolated from trout gut where it contributes to the physiological microflora [44], and it has been demonstrated to be an excellent example of an emerging pathogen in the context of this group, with proven pathogenic potential in salmonids [45]. S. pasteuri, on the other hand, has been isolated from an array of sources, including vegetables, goat milk, fermented pork sausages, and drinking water supplies. It has also been detected in the gastrointestinal tract of children with active celiac disease and in human vomit, urine, blood, and periprosthetic tissue $[46,47]$. S. epidermidis is a coagulase-negative Staphylococci and an important commensal organism of the human skin and mucous membranes. According to emerging evidence, its presence seems to convey benefits for human health through fighting harmful microorganisms. However, S. epidermidis can also be the cause of opportunistic infections, particularly biofilm-associated infections on indwelling medical devices [48]. Of the coagulase-negative staphylococci (CoNS), $S$. hominis is one of the three most frequently identified isolates recoverable from the blood of neonates and immunosuppressed patients and has been identified as a causal agent of bacteremia, septicemia, and endocarditis [49]. The presence of these Staphilococci species in the olive oil is almost certainly due to human contamination, probably due to the manual harvesting of the olives. Micrococci are gram-positive G+C-rich, non-motile, non-spore-forming actinomycetous bacteria. Micrococcus includes 10 members, with Micrococcus luteus being the type species. Members of this genus play important roles in the biodegradation of xenobiotics, bioremediation processes, and the production of biotechnologically important enzymes or bioactive compounds [50]. Lysinibacillus spp. belong to the family Bacillaceae. Lysinibacillus spp. have been found associated with plants but also isolated from air and natural soil habitats [51]. Finally, a strain of L. rhamnosus was found. L. rhamnosus belongs to the Lactobacillus casei group (LCG), which also includes the closely related Lactobacillus casei and Lactobacillus paracasei. LCG species are some of the most widely studied species due to their commercial, industrial, and applied health potentials [52]. Commercially, they are used to ferment dairy products. They have also been found to produce many bioactive metabolites able to confer host benefits when consumed [53]. As such, many LCG strains are considered probiotics. Among these, L. rhamnosus GG (LGG) is perhaps one of the most studied bacterial strains in relation to health applications [54].

It is important to underline that no pathogenic bacteria were isolated from the analyzed olive oils. This datum lies in agreement with that recently reported by Zullo et al. [12], who were unable to isolate any coliform bacteria from the different olive oils investigated and who concluded that any contaminating coliform bacteria must be destroyed in the oil mill during the malaxation of the paste that is usually richer in phenol compounds compared with the extracted olive oil. Considering the array of bacteria isolated in the present work, the malaxation effect described by Zullo et al. [12] is probably only relevant to coliform bacteria. In particular, as showed by Peng et al. [55], the presence of oleuropein in olive oil displays bidirectional activities in that it accelerates the growth of Lactobacillus strains but suppresses the growth of enteric bacterial pathogens. The presence of a strain of L. rhamnosus in one of the olive oils analyzed in this work supports the findings of Peng et al. [55], but we can also postulate that other bacterial species may have benefited from the presence of oleuropein and phenol compounds. 


\subsection{Enzymatic Tests and Biofilm Formation}

Most of the bacteria isolated in this work had never previously been isolated from olive oils. All bacteria were tested to elucidate their enzymatic activities ( $\beta$-glucosidase, $\beta$-glucanase, lipase, decarboxylase, and catalase) (Table 2). It is known that these activities are involved in the reduction of phenols and other olive oil molecules [6]. Most of the strains analyzed here showed very low $\beta$-glucosidase activity, except one strain of B. amyloliquefaciens and one strain of Pantoea that showed strong activity. Strong $\beta$-glucanase activity was exhibited by only one strain of B. amyloliquefaciens, two strains of Brevibacillus spp., one strain of S. hominis, and one strain belonging to Pantoea spp. Strong catalase activity was evident for two strains of $B r$. agri, one strain of B. subtilis, and one strain of Bacillus spp. Strong decarboxylase activity was shown by eight strains of B. amyloliquefaciens, four strains of B. subtilis, two strains of Brevibacillus spp., one strain of Br. agri, and one strain of Micrococcus spp. Finally, we found strong lipase activity in 10 strains of B. amyloliquefaciens, four strains of B. subtilis, two strains of Br. agri, one strain of B. megaterium, one strain of Br. invocatus, and one strain of Brevibacillus spp. All the other strains showed moderate, weak, or no enzymatic activities. As reported, the Bacillus spp. groups were the most active enzymatically.

As regards the $\beta$-glucosidase activity, only two isolates showed this activity. In olive oil environment this is an important activity because the enzyme $\beta$-glucosidase degrades the oleuropein, the main phenolic compound present in olives, that gives an intense bitter taste [9]. The $\beta$-glucanase activity resulted positive in only five isolates. The $\beta$-glucanase hydrolyzes secoiridoid glycosides, with the releasing of antioxidant molecules [56]. Only four isolates showed peroxidase activity. This enzyme degrades the phenolic compounds and polyphenols and effects the sensorial qualities of olive oils [57]. As regards to the decarboxylase activity, 16 isolates showed this activity. The decarboxylation is also considered a negative activity because it leads to the production of biogenic amines able to trigger allergic and inflammatory reactions in humans [58].

Finally, it is important to emphasize the significance of the lipase activities displayed by some of the olive oil microorganisms isolated in this work. This activity has negative consequences in olive oil in terms of lipolytic activity [4] while being of great interest from a biotechnological standpoint. Indeed, microorganisms able to tolerate and/or metabolize oils can be used for the bioremediation of oily wastewaters and contaminated soils [10,59-61], and provide a source of biosurfactants [62,63]. Such bacteria may also be useful in other commercial sectors including the food, pharmaceutical, and cosmetics industries [63].

The ability of some microorganisms to form biofilms has generated much debate about the potential threat that these microorganisms, in this case bacteria, may pose to human health. In fact, while microbial adherence, in particular adherence to plastic or human tissues, is widely considered a threat for human health in terms of it providing a route to pathogenic contamination (for example, via indwelling medical devices such as urinary catheters), it is also seen as a highly positive trait, especially for probiotic microorganisms able to adhere to and persist in the gastro-intestinal tract [64]. Of the bacteria isolated in this work, the following showed strong biofilm formation ability: Eight strains of B. amyloliquefaciens, four strains of B. agri, one strain of B. subtilis, one strain of Br. parabrevis, and one strain of L. rhamnosus and Pantoea spp. Moderate ability was exhibited by two strains of B. subtilis and Micrococcus spp. and one strain of B. invocatus, B. amyloliquefaciens, S. hominis, Pantoea spp., and Brevibacillus spp. (Table 3). Considering these results, it is important to highlight the biofilm formation ability exhibited by the Bacillus spp. belonging to the PGPR, especially the B. subtilis/B. amyloliquefaciens group. Indeed, biofilms formed by this species in agricultural contexts confer important biocontrol properties [65]. In particular, it has been shown that many wild strains of B. subtilis are capable of forming biofilms on plant root surfaces and that biofilm formation increases cell colonization efficiency and enhances local concentrations of antibiotics that work as signal molecules and stimulate biofilm formation [66]. Finally, it is important to call attention to the ability of L. rhamnosus to form a biofilm. It is well documented that the ability to adhere to mammalian tissues constitutes a crucial feature that potential probiotic bacteria must exhibit if they are to adapt to the gastrointestinal tract [64]. The strain of L. rhamnosus isolated here (as described later on), however, showed no resistance to acid or bile salts. 
Table 2. Enzymatic activities of bacteria.

\begin{tabular}{|c|c|c|c|c|c|c|c|c|c|c|c|c|c|c|c|c|c|c|c|c|c|}
\hline \multirow{2}{*}{ Strains } & \multirow{2}{*}{$\begin{array}{c}\text { No. } \\
\text { Isolates }\end{array}$} & \multicolumn{4}{|c|}{ Glucosidase } & \multicolumn{4}{|c|}{ Glucanase } & \multicolumn{4}{|c|}{ Lipase } & \multicolumn{4}{|c|}{ Decarboxylase } & \multicolumn{4}{|c|}{ Catalase } \\
\hline & & $\mathbf{N}$ & $\mathbf{W}$ & $\mathbf{M}$ & $\mathrm{S}$ & $\mathbf{N}$ & $\mathbf{W}$ & $\mathbf{M}$ & $\mathrm{S}$ & $\mathbf{N}$ & W & $\mathbf{M}$ & $\mathrm{S}$ & $\mathbf{N}$ & $\mathbf{W}$ & $\mathbf{M}$ & $\mathrm{S}$ & $\mathbf{N}$ & $\mathbf{W}$ & $\mathbf{M}$ & $\mathrm{S}$ \\
\hline B. amyloliquefaciens & 11 & 4 & 4 & 1 & 2 & 1 & - & 9 & 1 & - & - & 1 & 10 & 2 & - & 1 & 8 & 9 & - & 2 & - \\
\hline B. megaterium & 1 & - & 1 & - & - & 1 & - & - & - & - & - & - & 1 & - & 1 & - & - & - & 1 & - & - \\
\hline B. subtilis & 5 & - & 1 & 4 & - & - & - & 5 & - & - & 1 & - & 4 & 1 & - & - & 4 & 1 & - & 3 & 1 \\
\hline Br. agri & 9 & 7 & 1 & 1 & - & 3 & 2 & 4 & - & 2 & 1 & 4 & 2 & 8 & - & - & 1 & 4 & - & 3 & 2 \\
\hline Br. parabrevis & 3 & 3 & - & - & - & 3 & - & - & - & - & 1 & 1 & 1 & - & 3 & - & - & 2 & 1 & - & - \\
\hline Br. invocatus & 6 & 4 & 2 & - & - & 5 & - & 1 & - & - & 1 & 4 & 1 & 2 & 6 & - & - & 6 & - & - & - \\
\hline L. rhamnosus & 1 & 1 & & - & - & 1 & - & - & - & 1 & - & - & - & 1 & - & - & - & 1 & - & - & - \\
\hline S. epidermidis & 1 & 1 & - & - & - & 1 & - & - & - & 1 & - & - & - & 1 & - & - & - & 1 & - & - & - \\
\hline S. pasteuri & 1 & - & 1 & - & - & - & - & 1 & - & 1 & - & - & - & 1 & - & - & - & 1 & - & - & - \\
\hline S. hominis & 2 & 1 & 1 & - & - & - & 1 & - & 1 & - & 1 & 1 & - & - & 1 & - & - & 1 & - & - & - \\
\hline K. rhizophila & 1 & - & 1 & - & - & 1 & - & - & - & 1 & - & - & - & 1 & - & - & - & - & 1 & - & - \\
\hline Brevibacillus spp. & 4 & 3 & 1 & - & - & 2 & - & - & 2 & 2 & - & 1 & 1 & 2 & - & 2 & 2 & 3 & - & - & 1 \\
\hline Pantoea spp. & 3 & 1 & 1 & - & 1 & 2 & - & - & 1 & 2 & - & 1 & - & 2 & - & - & - & 1 & 1 & 1 & - \\
\hline Lysinbacillus spp. & 1 & - & 1 & - & - & 1 & - & - & - & - & - & 1 & - & 1 & - & - & - & - & - & 1 & - \\
\hline Micrococcus spp. & 3 & 2 & 1 & - & - & 2 & 1 & - & - & 2 & - & 1 & - & 2 & - & - & 1 & 3 & - & - & - \\
\hline
\end{tabular}

N: No activity; W: Weak activity, M: Moderate activity; S: Strong activity. Hyphen (-) indicates that none of the isolates of the specific species has a certain enzymatic activity level. 
Table 3. Biofilm formation of bacteria.

\begin{tabular}{|c|c|c|c|c|c|}
\hline \multirow{2}{*}{ Strain } & \multirow{2}{*}{ No. Isolates } & \multicolumn{4}{|c|}{ Adhesion to Plastic } \\
\hline & & No Biofilm & Weak & Moderate & Strong \\
\hline B. amyloliquefaciens & 11 & - & 2 & 1 & 8 \\
\hline B. megaterium & 1 & 1 & - & - & - \\
\hline B. subtilis & 5 & - & 3 & 1 & 1 \\
\hline Br. agri & 9 & 1 & 3 & 1 & 4 \\
\hline Br. parabrevis & 3 & - & 2 & - & 1 \\
\hline Br. invocatus & 6 & - & 5 & 1 & - \\
\hline L. rhamnosus & 1 & - & - & - & 1 \\
\hline S. epidermidis & 1 & - & 1 & - & - \\
\hline S. pasteuri & 1 & - & 1 & - & - \\
\hline S. hominis & 2 & - & 1 & 1 & - \\
\hline K. rhizophila & 1 & - & 1 & - & - \\
\hline Staphylococcus spp. & 1 & - & - & 1 & - \\
\hline Brevibacillus spp. & 4 & - & 3 & 1 & - \\
\hline Pantoea spp. & 3 & - & 1 & 1 & 1 \\
\hline Lysinbacillus spp. & 1 & 1 & - & - & - \\
\hline Micrococcus spp. & 3 & - & 1 & 2 & - \\
\hline
\end{tabular}

Hyphen (-) indicates that none of the isolates of the specific species has a certain adhesion level.

\subsection{Acid and Bile Salt Resistance of Bacterial Isolates}

Acid and bile salt resistance tests provide good indexes of the ability of microorganisms to survive in the gastrointestinal tract. These microorganisms may be viewed positively if the specific isolates in question are being considered as potential probiotics or negatively if the microorganisms are identified as potential pathogens. Zullo and Ciafardini [1] recently showed that some olive-borne yeasts exhibit probiotic potential, but with the exception of our previous preliminary study [9], to the best of our knowledge this present study is the first to test bacteria isolated from olive oils for their probiotic potential. The following isolated bacteria showed strong acid resistance: Five strains of $B$. amyloliquefaciens, five strains of B. subtilis, and one strain of Br. agri, Br. invocatus, S. hominis, Brevibacillus spp., and Pantoea spp. Moreover, three strains of B. subtilis, two strains of B. amyloliquefaciens, $S$. hominis, Pantoea spp., and one strain of Br. agri, K. rhizophila, and Micrococcus spp. showed strong bile salt resistance (Table 4). As long as these isolates are not also characterized by negative enzymatic or potential pathogenic activities, their presence in the olive oils or their utilization in other food matrices could be seen as positive due to their probiotic potential. In this context, it is important to underline the recent interest being directed toward spore-forming bacilli used for many centuries for the production and preservation of food. Specifically, Bacillus spp. are receiving much attention in the field of functional food research due to their enhanced tolerance and ability to survive in the hostile environment of the gastrointestinal tract. Moreover, bacilli are highly stable during food processing and storage, making them highly suitable candidates for health-promoting formulations [67]. 
Table 4. Acidic and bile tests.

\begin{tabular}{|c|c|c|c|c|c|c|c|c|c|}
\hline \multirow{2}{*}{ Strains } & \multirow{2}{*}{ No. Isolates } & \multicolumn{4}{|c|}{ pH 2.5} & \multicolumn{4}{|c|}{ Bile Salt $1.5 \%$} \\
\hline & & $\mathbf{N}$ & $\mathbf{W}$ & $\mathbf{M}$ & $S$ & $\mathbf{N}$ & $\mathbf{W}$ & $\mathbf{M}$ & $\mathrm{S}$ \\
\hline B. amyloliquefaciens & 11 & 1 & 5 & - & 5 & 6 & 2 & 1 & 2 \\
\hline B. megaterium & 1 & 1 & - & - & - & & 1 & - & - \\
\hline B. subtilis & 5 & - & - & - & 5 & - & 2 & - & 3 \\
\hline Br. agri & 9 & 7 & 1 & - & 1 & 5 & 1 & 2 & 1 \\
\hline Br. parabrevis & 3 & 2 & - & 1 & - & 1 & 2 & - & - \\
\hline Br. invocatus & 6 & 5 & - & - & 1 & 6 & - & - & - \\
\hline L. rhamnosus & 1 & 1 & - & - & - & 1 & - & - & - \\
\hline S. epidermidis & 1 & 1 & - & - & - & 1 & - & - & - \\
\hline S. pasteuri & 1 & 1 & - & - & - & 1 & - & - & - \\
\hline S. hominis & 2 & - & 1 & - & 1 & - & - & - & 2 \\
\hline K. rhizophila & 1 & - & 1 & - & - & - & - & - & 1 \\
\hline Staphylococcus spp. & 1 & 1 & - & - & - & 1 & - & - & - \\
\hline Brevibacillus spp. & 4 & - & 1 & 2 & 1 & 1 & 1 & - & 2 \\
\hline Pantoea spp. & 3 & 1 & - & - & 1 & - & - & - & 2 \\
\hline Lysinbacillus spp. & 1 & 1 & - & - & - & 1 & - & - & - \\
\hline Micrococcus spp. & 3 & 3 & - & - & - & 2 & - & - & 1 \\
\hline
\end{tabular}

N: Non-resistant; W: Weak; M: Moderate; S: Strong. Hyphen (-) indicates that none of the isolates of the specific species has a certain resistance level to $\mathrm{pH}$ or bile salt.

Thus, based on the results obtained, the probiotic candidature of the spore-forming B. subtilis and B. amyloliquefaciens isolated and characterized in this work may be considered. Last but not least, the isolation of a strain of L. rhamnosus was significant because, although this LCG showed no resistance to acid or bile salts, olive oil is a non-typical habitat for this species, making its presence there a noteworthy finding.

\subsection{Antimicrobial Resistance of Bacteria}

Antimicrobial resistance is becoming a real problem due to the extensive use of antibiotics in both humans and animals. It has been estimated that antimicrobial resistance causes 25,000 deaths annually in the European Union and 23,000 in the US [14].

In this work, we tested all the isolates against a plethora of antibiotics chosen according to the recommendation by the European Food Safety Authority (EFSA) as main classes of antimicrobials employed in human and veterinary treatments. We obtained some remarkable results, as shown below. The species-related differences in the sensitivities of the strains to different concentrations of vancomycin, tetracycline, and chloramphenicol were observed among the three Bacillus spp. All the Bacillus spp. strains tested were susceptible to vancomycin (MIC range: $0.25-4 \mathrm{mg} / \mathrm{L}$ ), tetracycline $(0.5-16 \mathrm{mg} / \mathrm{L})$, chloramphenicol $(1-4 \mathrm{mg} / \mathrm{L})$, erythromycin $(0.25 \mathrm{mg} / \mathrm{L})$, and ciprofloxacin $(0.25 \mathrm{mg} / \mathrm{L})$. Regarding clindamycin, all the B. amyloliquefaciens strains had MICs in the range of 0.5 to $1 \mathrm{mg} / \mathrm{L}$, with a distribution of MIC values similar to that reported by Agersø et al. [14]. B. subtilis strains had MICs in the range of 2 to $4 \mathrm{mg} / \mathrm{L}$, while the only strain of $B$. megaterium analyzed was resistant, in agreement with Agersø et al. [14], who found almost all B. megaterium strains to be resistant to clindamycin. The high resistance to clindamycin is probably, according to Adimpong et al. [68], an intrinsic characteristic of this species, as shown for B. licheniformis. Only one strain of B. subtilis and one strain of B. amyloliquefaciens were resistant to streptomycin, with MICs of 32 and $16 \mathrm{mg} / \mathrm{L}$, respectively. In B. amyloliquefaciens, the resistance to streptomycin was attributed to the presence of a putative 
aminoglycoside 6-adenylyltransferase gene [14] with high similarity to the aadk gene that confers resistance to B. subtilis [69]. The MICs of other Bacillus isolates varied from 1 to $8 \mathrm{mg} / \mathrm{L}$. Agersø and colleagues [14] proposed epidemiological cut-off values (ECOFF) for streptomycin of 2 and $8 \mathrm{mg} / \mathrm{L}$ for B. megaterium and B. amyloliquefaciens species, respectively, whereas the ECOFF value for streptomycin proposed by the European Food Safety Authority (EFSA) for Bacillus spp. in general is $8 \mathrm{mg} / \mathrm{L}$. For ampicillin, our results confirmed those obtained by Agersø et al. [14].

All isolates of Brevibacillus spp. were susceptible to vancomycin, tetracycline, ampicillin, ciprofloxacin, and chloramphenicol. For clindamycin, differences in the sensitivities were noticed for the isolated strains of Brevibacillus spp., for which the MIC values ranged from $0.5-8 \mathrm{mg} / \mathrm{L}$. Only one isolate of $B$. agri was susceptible, with an ECOFF valve of $4 \mathrm{mg} / \mathrm{L}$, in line with the data published by the EFSA (2018) for Bacillus spp. The species showing the most sensitivity to clindamycin were the Br. invocatus isolates. Several Brevibacillus spp. isolates showed streptomycin resistance. Pawlowski et al. [70] recently revealed a correlation between the presence of a streptomycin 6-nucleotidyltransferase gene (ant(6)-Ic) in Brevibacillus brevis and sensitivity to streptomycin. One isolate of Br. agri was resistant to erythromycin. Pawlowski et al. [70] identified a macrolide kinase gene ( $m p h J)$ within the resistome of $B r$. brevis that heterologously expressed $m p h J$ in E. coli and conferred resistance to erythromycin. Although this gene is only weakly expressed, it is feasible that it is involved in other metabolic processes in $B$. brevis VM4.

Brevibacillus spp. are occasionally used as biocontrol agents for promoting plant growth and protection from plant pathogens. In this regard, Pawlowski et al. [70] underlined that the utilization of antibiotics in agriculture may have resulted in the rapid dissemination of resistance genes from these genera into other plant pathogens and environmental bacteria. For these reasons, these genera should be carefully studied for their ability to mobilize resistance genes in areas/situations where the use of antibiotics is high.

All Staphylococcus isolates were susceptible to vancomycin (MIC range: $0.5-4 \mathrm{mg} / \mathrm{L}$ ) and chloramphenicol (2-8 mg/L); in contrast, they showed resistance to clindamycin $(0.5-4 \mathrm{mg} / \mathrm{L})$, and three out of the four strains isolated were resistant to tetracycline. Another study reported Staphylococcus spp. to be relatively susceptible to clindamycin [71]. The genetic determinants underlying the resistance of coagulase-negative staphylococci to clindamycin, erythromycin, and tetracycline were attributed to the presence of $\operatorname{erm}(C), m p h(C), \operatorname{erm}(A), \operatorname{tet}(L)$, and tet $(K)$ genes [72]. A multidrug resistance phenotype was observed in an isolate of $S$. hominis (resistance to six out of the eight antibiotics tested was observed).

All Micrococcus isolates were susceptible to erythromycin and chloramphenicol, whilst being resistant to clindamycin. The K. rizophila isolate was susceptible to almost all the antimicrobial agents tested with the exception of ciprofloxacin, confirming the data of Savini et al. [41]. Although these seem to be reassuring, many authors have confirmed that Kocuria spp. is emerging as a human pathogen, in particular in compromised hosts with severe disease (see the review of Purty et al. [73]).

The one strain of Lactobacillus spp. isolated here, L. rhamnosus, has previously been shown by several authors to exhibit resistance to just a single antibiotic, vancomycin. In fact, Lactobacillus spp. demonstrate intrinsic resistance to this antibiotic, which is also the best characterized intrinsic resistance mechanism [74]. Finally, the two Pantoea spp. isolates identified were both resistant to erythromycin, ampicillin, ciprofloxacin, and streptomycin. One strain also demonstrated high resistance to clindamycin, vancomycin, and erythromycin. Finally, Agnew et al. [75] reported that Pantoea species isolates from Brent geese cloacal swabs can be considered opportunistic pathogens due to their antimicrobial resistance features, helped by their environmental dissemination due to the migratory movements of these birds. All data related to antibiotic resistance are summarized in Table 5. 
Table 5. Antibiotics suceptibility (MIC expressed in mg/L).

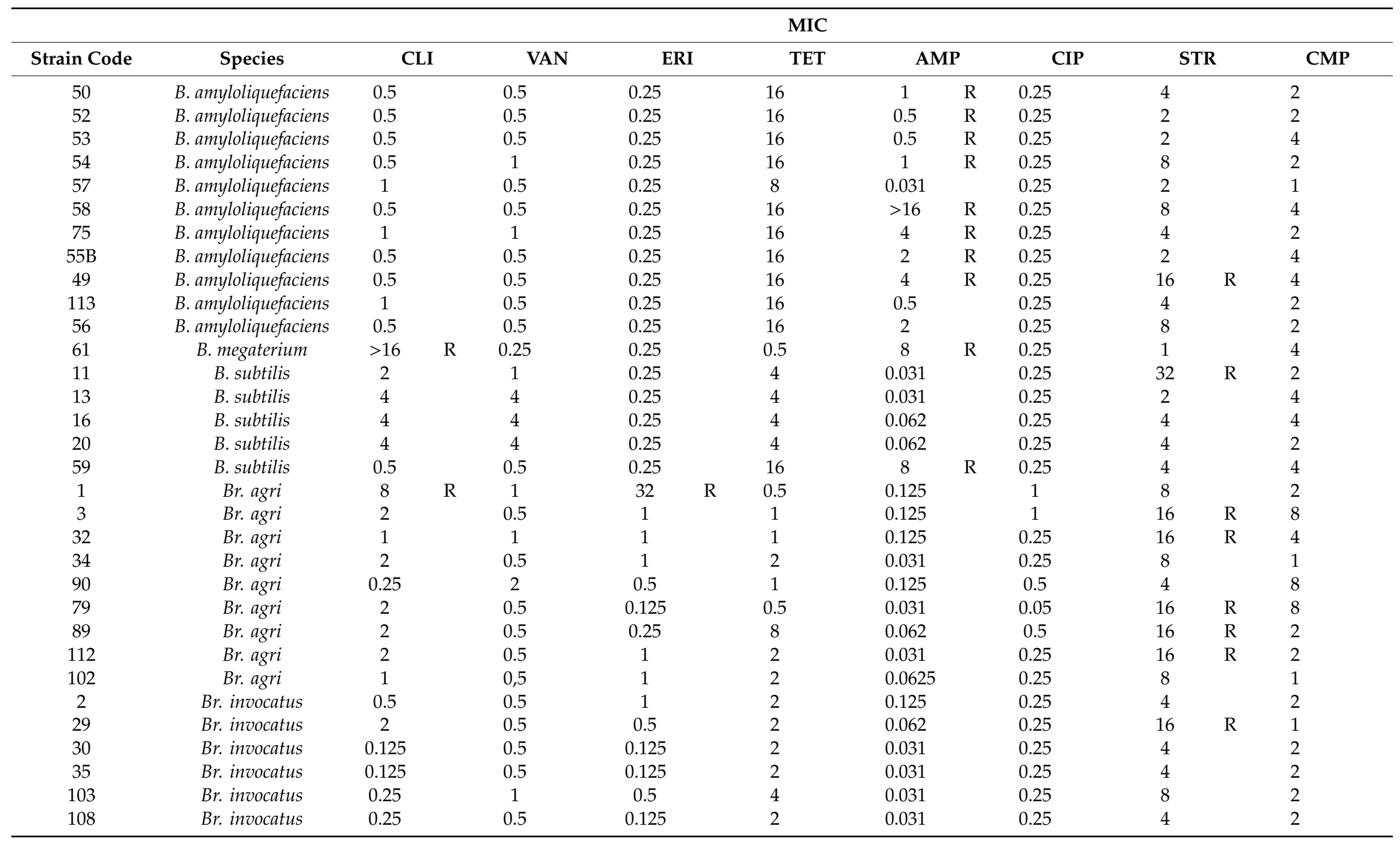


Table 5. Cont.

\begin{tabular}{|c|c|c|c|c|c|c|c|c|c|c|c|c|c|c|c|c|c|}
\hline \multirow{3}{*}{$\begin{array}{c}\text { Strain Code } \\
104\end{array}$} & \multicolumn{17}{|c|}{ MIC } \\
\hline & Species & \multicolumn{2}{|c|}{ CLI } & \multicolumn{2}{|c|}{ VAN } & \multicolumn{2}{|c|}{ ERI } & \multicolumn{2}{|c|}{ TET } & \multicolumn{2}{|c|}{ AMP } & \multicolumn{2}{|c|}{ CIP } & \multicolumn{2}{|c|}{ STR } & \multicolumn{2}{|c|}{ CMP } \\
\hline & Br. parabrevis & 4 & & 1 & & 0.5 & & 2 & & 8 & $\mathrm{R}$ & 0.25 & & 64 & $\mathrm{R}$ & 4 & \\
\hline 71 & Br. parabrevis & 0.25 & & 4 & & $>8$ & $\mathrm{R}$ & 2 & & $>16$ & $\mathrm{R}$ & 0.5 & & 4 & & $>64$ & $\mathrm{R}$ \\
\hline 91 & Br. parabrevis & 0.25 & & 1 & & 0.5 & & 2 & & 0.031 & & 0.25 & & 8 & & 1 & \\
\hline 60TC2 & S. hominis & 1 & $\mathrm{R}$ & 0.5 & & 1 & & 0.125 & & 0.031 & & 0.25 & & 16 & $\mathrm{R}$ & 2 & \\
\hline $63 \mathrm{~B} 10$ & S. hominis & 0.5 & $\mathrm{R}$ & 4 & & $>8$ & $\mathrm{R}$ & $>64$ & $\mathrm{R}$ & 16 & $\mathrm{R}$ & 2 & $\mathrm{R}$ & 32 & $\mathrm{R}$ & 8 & \\
\hline $70 \mathrm{~B}$ & S. pasteuri & 2 & $\mathrm{R}$ & 1 & & 0.25 & & 4 & $\mathrm{R}$ & 0.125 & & 0.25 & & 8 & & 4 & \\
\hline 73 & S. epidermidis & 4 & $\mathrm{R}$ & 0.5 & & 0.25 & & 2 & $\mathrm{R}$ & 0.031 & & 0.25 & & 2 & & 4 & \\
\hline $49 \mathrm{C} 1$ & K. rizophila & 0.125 & & 2 & & 0.125 & & 0.25 & & 0.031 & & 2 & $\mathrm{R}$ & 1 & & 2 & \\
\hline 4 & L. rhamnosus & 0.25 & & $>128$ & $\mathrm{R}$ & 1 & & 2 & & 1 & & 1 & & 2 & & 2 & \\
\hline 221 & Lysinibacillus spp. & 8 & $\mathrm{R}$ & 1 & & 8 & $\mathrm{R}$ & 2 & & 0.25 & & 2 & & 32 & $\mathrm{R}$ & 4 & \\
\hline 40B3 & Micrococcus spp. & 1 & $\mathrm{R}$ & 2 & & 0.5 & & 0.5 & & 0.25 & & 1 & & 4 & & 2 & \\
\hline $60 \mathrm{TC} 1$ & Micrococcus spp. & 1 & $\mathrm{R}$ & 1 & & 0.25 & & 4 & $\mathrm{R}$ & 0.25 & & 2 & $\mathrm{R}$ & 2 & & 4 & \\
\hline 225 & Micrococcus spp. & 4 & $\mathrm{R}$ & 32 & $\mathrm{R}$ & 1 & & 1 & & 8 & $\mathrm{R}$ & 0.25 & & 8 & & 4 & \\
\hline 227 & Brevibacillus spp. & 2 & & 1 & & 0.125 & & 0.5 & & 0.031 & & 0.25 & & 4 & & 4 & \\
\hline 31 & Brevibacillus spp. & 1 & & 0.5 & & 1 & & 2 & & 0.031 & & 0.25 & & 16 & $\mathrm{R}$ & 2 & \\
\hline 94 & Brevibacillus spp. & 4 & & 4 & & 0.25 & & 4 & $\mathrm{R}$ & 0.062 & & 0.25 & & 2 & & 4 & \\
\hline $226 B$ & Pantoea spp. & 1 & & 2 & & $>8$ & $\mathrm{R}$ & 0.25 & & 16 & $\mathrm{R}$ & 16 & $\mathrm{R}$ & 64 & $\mathrm{R}$ & 8 & \\
\hline $223 \mathrm{~A}$ & Pantoea spp. & 2 & & 0.5 & & 0.25 & & 1 & & 0.062 & & 1 & & 8 & & 16 & \\
\hline
\end{tabular}

AMP: Ampicilin; VAN: Vancomycin; ERI: Erythromycin; TET: Tetracycline; CLI: Clindamycin; TR: Streptomycin; CIP: Ciprofloxacin; CMP: Chloramphenicol; R: Resistant. The epidemiological cut-off values, namely the MIC that separate a population into isolates with and without acquired or mutational resistance, were retrieved from the European Food Safety Authority (EFSA, 2012 and 2018) and from Agersø et al. (2018). For antibiotics not covered by EFSA, breakpoints from Clinical and Laboratory Standards Institute (CLSI) were used (CLSI, M100-S25, 2015). For S. hominis, S. epidermidis and S. pasteuri, the cut-offs of EUCAST (https://mic.eucast.org) were used. The values indicated represent the MIC of every single isolate when subjected to a range of different antibiotics at different concentrations, according to EFSA, CLSI, and the European Committee on Antimicrobial Susceptibility Testing (EUCAST). Unless otherwise stated with resistance (R), isolates are sensitive to the antibiotics. 


\section{Conclusions}

In this preliminary work, we showed that in olive oil, which is considered an unfavorable substrate for microbial growth microflora, there are different bacterial species, and that both frequency and diversity of the bacterial species isolated depend on olive variety. Indeed, olive oil bacteria, together with yeasts, may influence chemical sensorial properties of olive oils during storage. However, they also represent a reservoir of microbial diversity that needs further consideration. On the one hand, some of the species found show an interesting biotechnological potential for industrial bioconversion of lipids, fats, and oils into high-value products and as plant growth-promoting rhizobacteria, chemical fertilizer substitutes, for their potential ability to detoxify industrial or agro-industrial byproducts. Moreover, Bacillus spp. and L. rhamnosus have a probiotic potential that may be explored in view of the possible probiotic utilization of some extra virgin olive oils. On the other hand, most of the isolates showed different patterns of antibiotic resistance, thus posing safety issues on the possible biotechnological exploitation of this microbial biodiversity.

Supplementary Materials: The following are available online at http:/www.mdpi.com/2076-2607/8/1/97/s1.

Author Contributions: Each author contributed to the research and this publication in ways including: Conceptualization, S.Z., M.S. and F.F.; methodology, S.Z., F.F., G.Z.; formal analysis, F.F., C.M.; investigation, F.F., S.Z., P.D.; resources, S.Z. and S.D.; data curation, F.F.; writing-original draft, S.Z. and F.F.; writing-review and editing, S.Z., F.F., M.S., G.Z., I.M., M.B. and S.D.; supervision, S.Z.; funding acquisition, S.Z. and S.D. All authors have read and agreed to the published version of the manuscript.

Funding: This research was partially funded by Ministero dell'Istruzione, dell'Università e della Ricerca, Italy. Grant number 2017B7MMJ5_001.

Acknowledgments: We thank Stephanie Parsley of Eureka Editing for the English language revision.

Conflicts of Interest: The authors declare no conflict of interest.

\section{References}

1. Zullo, B.A.; Ciafardini, G. Evaluation of physiological properties of yeast strains isolated from olive oil and their in vitro probiotic trait. Food Microbiol. 2019, 78, 179-187. [CrossRef]

2. Porru, C.; Rodríguez-Gómez, F.; Benítez-Cabello, A.; Jiménez-Díaz, R.; Zara, G.; Budroni, M.; Mannazzu, I.; Arroyo-López, F.N. Genotyping, identification and multifunctional features of yeasts associated to Bosana naturally black table olive fermentations. Food Microbiol. 2018, 69, 33-42. [CrossRef]

3. Ciafardini, G.; Zullo, B.A. Survival of microorganisms in extra virgin olive oil. Food. Microbiol. 2002, 19, 105-109. [CrossRef]

4. Ciafardini, G.; Zullo, B.A.; Cioccia, G.; Iride, A. Lypolitic activity of Williopsis californica, and Saccharomyces cerevisiae in extra virgin olive oil. Int. J. Food Microbiol. 2006, 107, 27-32. [CrossRef]

5. Zullo, B.A.; Ciafardini, G. Lipolytic yeasts distribution in commercial extra virgin olive oil. Food Microbiol. 2008, 25, 970-977. [CrossRef]

6. Romo-Sanchez, S.; Alves-Baffi, M.; Arevalo-Villena, M.; Ubeda-Iranzo, J.; Briones- Perez, A. Yeast biodiversity from oleic ecosystems: Study of their biotechnological properties. Food Microbiol. 2010, 27, 487-492. [CrossRef]

7. Zullo, B.A.; Cioccia, G.; Ciafardini, G. Distribution of dimorphic yeast species in commercial extra virgin olive oil. Food Microbiol. 2010, 27, 1035-1042. [CrossRef]

8. Ciafardini, G.; Cioccia, G.; Zullo, B.A. Taggiasca extra virgin olive oil colonization by yeasts during the extraction process. Food Microbiol. 2017, 62, 58-61. [CrossRef]

9. Santona, M.; Sanna, M.L.; Multineddu, C.; Fancello, F.; de la Fuente, S.A.; Dettori, S.; Zara, S. Microbial biodiversity of Sardinian oleic ecosystems. Food Microbiol. 2018, 70, 65-75. [CrossRef]

10. Pizzolante, G.; Durante, M.; Rizzo, D.; Di Salvo, M.; Tredici, S.M.; Tufariello, M.; De Benedetto, G.E. Characterization of two Pantoea strains isolated from extra-virgin olive oil. AMB Express 2018, 8, 113. [CrossRef]

11. Koidis, A.; Triantafillou, E.; Boskou, D. Endogenous microflora in turbid virgin olive oils and the physicochemical characteristics of these oils. Eur. J. Lipid. Sci. Technol. 2008, 110, 164-171. [CrossRef] 
12. Zullo, B.A.; Maiuro, L.; Ciafardini, G. Survival of Coliform Bacteria in Virgin Olive Oil. BioMed Res. Int. 2018. [CrossRef]

13. Ciafardini, G.; Zullo, B.A. Virgin olive oil yeasts: A review. Food Microbiol. 2018, 70, 245-253. [CrossRef]

14. Agersø, Y.; Stuer-Lauridsen, B.; Bjerre, K.; Jensen, M.G.; Johansen, E.; Bennedsen, M.; Brockmann, E.; Nielsen, B. Antimicrobial susceptibility testing and tentative epidemiological cutoff values for five Bacillus species relevant for use as animal feed additives or for plant protection. Appl. Environ. Microbiol. 2018, 84, e01108-18. [CrossRef]

15. Deiana, P.; Santona, M.; Dettori, S.; Culeddu, N.; Dore, A.; Molinu, M.G. Multivariate approach to assess the chemical composition of Italian virgin olive oils as a function of variety and harvest period. Food Chem. 2019, 300, 125243. [CrossRef]

16. Deiana, P.; Santona, M.; Dettori, S.; Molinu, M.G.; Dore, A.; Culeddu, N.; Azara, E.; Naziri, E.; Tsimidou, M.Z. Can all the Sardinian varieties support the PDO “Sardegna” virgin olive oil? Eur. J. Lipid Sci. Technol. 2019, 121, 1800135. [CrossRef]

17. Fancello, F.; Petretto, G.L.; Sanna, M.L.; Pintore, G.; Lage, M.; Zara, S. Isolation and characterization of microorganisms and volatiles associated with Moroccan saffron during different processing treatments. Int. J. Food Microbiol. 2018, 273, 43-49. [CrossRef]

18. Mangia, N.; Fancello, F.; Deiana, P. Microbiological characterization using combined culture dependent and independent approaches of Casizolu pasta filata cheese. J. Appl. Microbiol. 2016, 120, 329-345. [CrossRef]

19. Godon, J.J.; Zumstein, E.; Dabert, P.; Habouzit, F.; Moletta, R. Molecular microbial diversity of an anaerobic digestor as determined by small-subunit rDNA sequence analysis. Appl. Environ. Microbiol. 1997, 63, 2802-2813. [CrossRef]

20. Rosi, 1.; Vinella, M.; Domizio, P. Characterization of beta-glucosidase activity in yeasts of oenological origin. J. Appl. Bacteriol. 1994, 77, 519-527. [CrossRef]

21. Strauss, M.L.; Jolly, N.P.; Lambrechts, M.G.; van Rensburg, P. Screening for the production of extracellular hydrolytic enzymes by non-Saccharomyces wine yeasts. J. Appl. Microbiol. 2001, 91, 182-190. [CrossRef] [PubMed]

22. Gardini, F.; Tofalo, R.; Belletti, N.; Iucci, L.; Suzzi, G.; Torriani, S.; Guerzoni, M.E.; Lanciotti, R. Characterization of yeasts involved in the ripening of Pecorino Crotonese cheese. Food Microbiol. 2006, 23, 641-648. [CrossRef] [PubMed]

23. Bou Zeidan, M.; Zara, G.; Viti, C.; Decorosi, F.; Mannazzu, I.; Budroni, M.; Giovannetti, L.; Zara, S. L-histidine inhibits biofilm formation and FLO11- associated phenotypes in Saccharomyces cerevisiae flor yeasts. PLoS ONE 2014, 9, e112141. [CrossRef] [PubMed]

24. Extremina, C.I.; Costa, L.; Aguiar, A.I.; Peixe, L.; Fonseca, A.P. Optimization of processing conditions for the quantification of enterococci biofilms using microtitre-plates. J. Microbiol. Methods 2011, 84, 167-173. [CrossRef]

25. Clinical and Laboratory Standards Institute (CLSI). Performance Standards for Antimicrobial Susceptibility Testing; 25th Informational Supplement. CLSI Document M100-S26; Clinical and Laboratory Standards Institute: Wayne, PA, USA, 2015.

26. EFSA Panel on Additives and Products or Substances used in Animal Feed (FEEDAP). Guidance on the assessment of bacterial susceptibility to antimicrobials of human and veterinary importance. EFSA J. 2012, 10, 2740.

27. EFSA Panel on Additives and Products or Substances used in Animal Feed (FEEDAP). Guidance on the characterization of microorganisms used as feed additives or as production organisms. EFSA J. 2018, 16, 5206.

28. Brenes, M.; Medina, E.; Romero, C.; de Castro, A. Antimicrobial activity of olive oil. J. Food Prot. 2007, 18, 6-8.

29. Hashem, A.; Tabassum, B.; Abd_Allah, E.F. Bacillus subtilis: A plant-growth promoting rhizobacterium that also impacts biotic stress. Saudi J. Biol. Sci. 2019, 26, 1291-1297. [CrossRef]

30. Cui, W.; He, P.; Munir, S.; He, P.; Li, X.; Li, Y.; Wu, J.; Wu, Y.; Yang, L.; He, P.; et al. Efficacy of plant growth promoting bacteria Bacillus amyloliquefaciens B9601-Y2 for biocontrol of southern corn leaf blight. Biol. Control 2019, 139, 104080. [CrossRef]

31. Muccee, F.; Ejaz, S.; Riaz, N. Toluene degradation via a unique metabolic route in indigenous bacterial species. Arch. Microbiol. 2019, 201, 1369. [CrossRef] 
32. Chatterjee, S.; Shekhawat, K.; Gupta, N. Bioreduction of toxic hexavalent chromium by novel indigenous microbe Brevibacillus agri isolated from tannery wastewater. Int. J. Environ. Sci. Technol. 2019, 16, 3549. [CrossRef]

33. Sanaa, M.F.; El-Rab, G.; Hifney, A.F.; Abdel-Basset, R. Costless and huge hydrogen yield by manipulation of iron concentrations in the new bacterial strain Brevibacillus invocatus SAR grown on algal biomass. Int. J. Hydrogen. Energ. 2018, 43, 18896-18907.

34. Pramila, R.; Padmavathy, K.; Vijaya, R.K.; Mahalakshmi, K. Brevibacillus parabrevis, Acinetobacter baumannii and Pseudomonas citronellolis-Potential candidates for biodegradation of low-density polyethylene (LDPE). Microbiol. Res. 2012, 4, 9-14. [CrossRef]

35. Walterson, A.M.; Stavrinides, J. Pantoea: Insights into a highly versatile and diverse genus within the Enterobacteriaceae. FEMS Microbiol. Rev. 2015, 39, 968-984. [CrossRef]

36. Vuletin Selak, G.; Raboteg, M.; Dubost, A.; Abrouk, D.; Žanić, K.; Normand, P.; Pujić, P. Whole-Genome Sequence of a Pantoea sp. Strain Isolated from an Olive (Olea europaea L.) Knot. Microbiol. Resour. Announc. 2019, 8, e00978-19. [CrossRef]

37. Hosni, T.; Moretti, C.; Devescovi, G.; Suarez-Moreno, Z.R.; Fatmi, M.B.; Guarnaccia, C.; Pongor, S.; Onofri, A.; Buonaurio, R.; Venturi, V. Sharing of quorumsensing signals and role of interspecies communities in a bacterial plant disease. ISME J. 2011, 5, 1857-1870. [CrossRef]

38. Marchi, G.; Sisto, A.; Cimmino, A.; Andolfi, A.; Cipriani, M.G.; Evidente, A.; Surico, G. Interaction between Pseudomonas savastanoi and Pantoea agglomerans in the olive knots. Plant Pathol. 2006, 55, 614-624. [CrossRef]

39. Buonaurio, R.; Moretti, C.; Passos da Silva, D.; Cortese, C.; Ramos, C.; Venturi, V. The olive knot disease as a model to study the role of interspecies bacterial communities in plant disease. Front. Plant Sci. 2015, 6, 434. [CrossRef]

40. Savini, V.C.; Catavitello, G.; Masciarelli, D.; Astolfi, A.; Balbinot, A.; Bianco, F.; Febbo, C.; D'Amario, D.; D'Antonio, C. Drug sensitivity and clinical impact of members of the genus Kocuria. J. Med. Microbiol. 2010, 59, 1395-1402. [CrossRef]

41. Takarada, H.; Sekine, M.; Kosugi, H.; Matsuo, Y.; Fujisawa, T.; Omata, S.; Kishi, E.; Shimizu, A.; Tsukatani, N.; Tanikawa, S.; et al. Complete genome sequence of the soil actinomycete Kocuria rhizophila. J. Bacteriol. 2008, 190, 4139-4146. [CrossRef]

42. Moreno-Andrés, J.; Acevedo-Merino, A.; Nebot, E. Study of marine bacteria inactivation by photochemical processes: Disinfection kinetics and growth modeling after treatment. Environ. Sci. Pollut. Res. 2018, 25, 27693. [CrossRef] [PubMed]

43. Bianco, A.; Fancello, F.; Balmas, V.; Dettori, M.; Motroni, A.; Zara, G.; Budroni, M. Microbial communities and malt quality of durum wheat used in brewing. J. Inst. Brew. 2019, 125, 222-229. [CrossRef]

44. Kim, D.H.; Brunt, J.; Austin, B. Microbial diversity of intestinal contents and mucus in rainbow trout Oncorhynchus mykiss. J. Appl. Microbiol. 2007, 102, 1654-1664. [CrossRef] [PubMed]

45. Pekala, A.; Paździor, E.; Antychowicz, J.; Bernad, A.; Głowacka, H.; Więcek, B.; Niemczuk, W. Kocuria rhizophila and Micrococcus luteus as emerging opportunist pathogens in brown trout Salmo trutta Linnaeus 1758 and rainbow trout Oncorhynchus mykiss Walbaum 1792. Aquaculture 2018, 486, 285-289. [CrossRef]

46. Savini, V.; Catavitello, C.; Bianco, A.; Balbinot, A.; D'Antonio, D. Epidemiology, pathogenicity and emerging resistances in Staphylococcus pasteuri: From mammals and lampreys, to man. Recent Pat. Antiinfect. Drug. Discov. 2009, 4, 123-129. [CrossRef]

47. Chesneau, O.; Morvan, A.; Grimont, F.; Labischinski, H.; El Solh, N. Staphylococcus pasteuri sp. nov., isolated from human, animal, and food specimens. Int. J. Syst. Bacteriol. 1993, 43, 237-244. [CrossRef]

48. Nguyen, T.H.; Park, M.D.; Otto, M. Host response to Staphylococcus epidermidis colonization and infections. Front. Cell. Infect. Microbiol. 2017, 7, 90. [CrossRef]

49. Mendoza-Olazarán, S.; Morfin-Otero, R.; Rodríguez-Noriega, E.; Llaca-Díaz, J.; Flores-Treviño, S.; González-González, G.M.; Garza-González, E. Microbiological and Molecular Characterization of Staphylococcus hominis Isolates from Blood. PLoS ONE 2013, 8, e61161. [CrossRef]

50. Dib, J.R.; Liebl, W.; Wagenknecht, M.; Farías, M.E.; Meinhardt, F. Extrachromosomal genetic elements in Micrococcus. Appl. Microbiol. Biotechnol. 2013, 97, 63. [CrossRef] 
51. Wong, A.; Junqueira, A.C.M.; Uchida, A.; Purbojati, R.W.; Houghton, J.N.I.; Chénard, C.; Clare, M.E.; Kushwaha, K.K.; Putra, A.; Gaultier, N.E.; et al. Complete genome sequence of Lysinibacillus sp. strain SGAir0095, isolated from tropical air samples collected in Singapore. Microbiol. Resour. Announc. 2019, 8, e00604-19. [CrossRef]

52. Hill, D.; Sugrue, I.; Tobin, C.; Hill, C.; Stanton, C.; Ross, R.P. The Lactobacillus casei Group: History and health related applications. Front. Microbiol. 2018, 9, 2107. [CrossRef] [PubMed]

53. Dietrich, C.G.; Kottmann, T.; Alavi, M. Commercially available probiotic drinks containing Lactobacillus casei Dn-114001 reduce antibiotic-associated diarrhea. World J. Gastroenterol. 2014, 20, 15837-15844. [CrossRef] [PubMed]

54. Segers, M.E.; Lebeer, S. Towards a better understanding of Lactobacillus rhamnosus Gg-host interactions. Microb. Cell Factorics 2014, 13, S7. [CrossRef]

55. Peng, M.; Xi, Z.; Debabrata, B. Polyphenols and tri-terpenoids from Olea europaea L. in alleviation of enteric pathogen infections through limiting bacterial virulence and attenuating inflammation. J. Funct. Foods 2017, 36, 132-143. [CrossRef]

56. Iconomou, D.; Arapoglou, D.; Israilides, C. Improvement of phenolic anitioxidants and quality characteristics of virgin olive oil with the addition of enzymes and nitrogen during olive paste processing. Grasas $Y$ Aceites 2010, 61, 303-311. [CrossRef]

57. Angerosa, F.; Mostallino, R.; Basti, C.; Vito, R.; Serraiocco, A. Virgin olive oil differentiation in relation to extraction methodologies. J. Sci. Food Agric. 2000, 80, 2190-2195. [CrossRef]

58. Bevilacqua, A.; Beneduce, L.; Sinigaglia, M.; Corbo, M.R. Selection of yeasts as starter cultures for table olives. J. Food Sci. 2013, 78, M742-M751. [CrossRef]

59. Ammar, E.; Nasri, M.; Medhioub, K. Isolation of phenol degrading Enterobacteria from the wastewater of olive oil extraction process. World. J. Microbiol. Biotechnol. 2005, 21, 253-259. [CrossRef]

60. Azhdarpoor, A.; Mortazavi, B.; Moussavi, G. Oily wastewaters treatment using Pseudomonas sp. isolated from the compost fertilizer. J. Environ. Health Sci. Eng. 2014, 12, 77. [CrossRef]

61. Kissi, M.; Mountadar, M.; Assobhei, O.; Gargiulo, E.; Palmieri, G.; Giardina, P. Roles of two white-rot basidiomycete fungi in decolorization and detoxification of olive mill wastewater. Appl. Microbiol. Biotechnol. 2001, 57, 221-226.

62. Maier, R. Biosurfactants: Evolution and diversity in Bacteria. Adv. Appl. Microbiol. 2003, 52, $101-121$. [PubMed]

63. Singh, A.; Hamme, J.D.; Ward, O.P. Surfactants in microbiology and biotechnology: Part 2: Application aspects. Biotechnol. Adv. 2007, 25, 99-121. [CrossRef] [PubMed]

64. Martín, R.; Chamignon, C.; Mhedbi-Hajri, N.; Chain, F.; Derrien, M.; Escribano-Vázquez, U.; Bermúdez-Humarán, L.G. The potential probiotic Lactobacillus rhamnosus CNCM I-3690 strain protects the intestinal barrier by stimulating both mucus production and cytoprotective response. Sci. Rep. 2019, 9, 5398. [CrossRef] [PubMed]

65. Cairns, L.S.; Hobley, L.; Stanley-Wall, N.R. Biofilm formation by Bacillus subtilis: New insights into regulatory strategies and assembly mechanisms. Mol. Microbiol. 2014, 93, 587-598. [CrossRef] [PubMed]

66. Chen, Y.; Yan, F.; Chai, Y.; Liu, H.; Kolter, R.; Losick, R.; Guo, J. Biocontrol of tomato wilt disease by Bacillus subtilis isolates from natural environments depends on conserved genes mediating biofilm formation. Environ. Microbiol. 2013, 15, 848-864. [CrossRef] [PubMed]

67. Elshaghabee, F.; Rokana, N.; Gulhane, R.D.; Sharma, C.; Panwar, H. Bacillus as potential probiotics: Status, concerns, and future perspectives. Front. Microbiol. 2017, 8, 1490. [CrossRef]

68. Adimpong, D.B.; Sørensen, K.I.; Thorsen, L.; Stuer-Lauridsen, B.; Abdelgadir, W.S.; Nielsen, D.S.; Derkx, P.M.F.; Jespersen, L. Antimicrobial susceptibility of Bacillus strains Isolated from primary starters for african traditional bread production and characterization of the bacitracin operon and bacitracin biosynthesis. Appl. Environ. Microbiol. 2012, 78, 7903-7914. [CrossRef]

69. Ohmiya, K.; Tanaka, T.; Noguchi, N.; O’Hara, K.; Kono, M. Nucleotide sequence of the chromosomal gene coding for the aminoglycoside 6-adenylyltransferase from Bacillus subtilis Marburg 168. Gene 1989, 78, 377-378.

70. Pawlowski, A.C.; Westman, E.L.; Koteva, K.; Waglechner, N.; Wright, G.D. The complex resistomes of Paenibacillaceae reflect diverse antibiotic chemical ecologies. ISME J. 2018, 12, 885-897. [CrossRef] 
71. Bannerman, T.L.; Peacock, S.J. Staphylococcus, Micrococcus, and Other Catalase- Positive Cocci. In Manual of Clinical Microbiology, 9th ed.; Murray, P.R., Baron, E.J., Jorgensen, J.H., Landry, M.L., Pfaller, M.A., Eds.; ASM Press: Washington, DC, USA, 2007; pp. 390-404.

72. Gómez, P.; Casado, C.; Sáenz, Y.; Ruiz-Ripa, L.; Estepa, V.; Zarazaga, M.; Torres, C. Diversity of species and antimicrobial resistance determinants of staphylococci in superficial waters in Spain. FEMS Microb. Ecol. 2017, 93. [CrossRef]

73. Purty, S.; Saranathan, R.; Prashanth, K.; Narayanan, K.; Asir, J.; Sheela Devi, C.; Kumar Amarnath, S. The expanding spectrum of human infections caused by Kocuria species: A case report and literature review. Emerg. Microbes Infect. 2013, 2, 1-8. [CrossRef] [PubMed]

74. Goldstein, E.; Tyrrell, K.L.; Citron, D.M. Lactobacillus species: Taxonomic complexity and controversial susceptibilities. Clin. Infect. Dis. 2015, 60, S98-S107. [CrossRef] [PubMed]

75. Agnew, A.; Wang, J.; Fanning, S.; Bearhop, S.; McMahon, B.J. Insights into antimicrobial resistance among long distance migratory East Canadian High Arctic light-bellied Brent geese (Branta bernicla hrota). Ir. Vet. J. 2015, 69, 13. [CrossRef] [PubMed]

(C) 2020 by the authors. Licensee MDPI, Basel, Switzerland. This article is an open access article distributed under the terms and conditions of the Creative Commons Attribution (CC BY) license (http://creativecommons.org/licenses/by/4.0/). 